OPEN ACCESS

Edited by:

Andrea Papadia,

University of Italian Switzerland,

Switzerland

Reviewed by:

Tjalling Bosse,

Leiden University Medical Center,

Netherlands

Martina Arcieri,

University of Messina, Italy

*Correspondence:

Camilla Nero

camilla.nero@policlinicogemelli.it

Specialty section:

This article was submitted to

Women's Cancer.

a section of the journal

Frontiers in Oncology

Received: 30 September 2020

Accepted: 29 July 2021

Published: 01 September 2021

Citation:

Nero C, Ciccarone F, Pietragalla A

Duranti S, Daniele G, Scambia G and Lorusso D (2021) Adjuvant Treatment

Recommendations in Early-Stage

Endometrial Cancer: What Changes

With the Introduction of The Integrated

Molecular-Based Risk Assessment.

Front. Oncol. 11:612450.

doi: 10.3389/fonc.2021.612450

\section{Adjuvant Treatment Recommendations in Early-Stage Endometrial Cancer: What Changes With the Introduction of The Integrated Molecular-Based Risk Assessment}

\author{
Camilla Nero ${ }^{1,2 *}$, Francesca Ciccarone ${ }^{1}$, Antonella Pietragalla ${ }^{1}$, Simona Duranti ${ }^{1}$, \\ Gennaro Daniele ${ }^{1}$, Giovanni Scambia ${ }^{1,2}$ and Domenica Lorusso ${ }^{1,2}$ \\ ${ }^{1}$ Direzione Scientifica, Fondazione Policlinico Universitario A. Gemelli IRCCS, Rome, Italy, ${ }^{2}$ Dipartimento di Scienze della vita \\ e sanità pubblica, Università Cattolica del Sacro Cuore, Rome, Italy
}

Adjuvant therapy recommendations for endometrial cancer were historically based on the individual patient's risk of disease recurrence using clinicopathologic factors such as age, stage, histologic subtype, tumor grade, and lymphovascular space invasion. Despite the excellent prognosis for early stages, considerable under- and overtreatment remains. Integrated genomic characterization by the Cancer Genome Atlas (TCGA) in 2013 defined four distinct endometrial cancer subgroups (POLE mutated, microsatellite instability, low copy number, and high copy number) with possible prognostic value. The validation of surrogate markers (p53, Mismatch repair deficiency, and POLE) to determine these subgroups and the addition of other molecular prognosticators (CTNNB1, L1CAM) resulted in a practical and clinically useful molecular classification tool. The incorporation of such molecular alterations into established clinicopathologic risk factors resulted in a refined, improved risk assessment. Thus, the ESGO/ESTRO/ESP consensus in 2020 defined for the first time different prognostic risk groups integrating molecular markers. Finally, the feasibility and clinical utility of molecular profiling for tailoring adjuvant therapy in the high-intermediate-risk group is currently under investigation (NCT03469674).

Keywords: endometrial cancer, molecular classification, adjuvant treatment, recommendations, risk factors

\section{OVERVIEW}

Endometrial cancer (EC) is the most common gynecological cancer in developed countries; the majority of cases are diagnosed at an early stage and addressed to surgical treatment (1). Traditionally, ECs have been categorized into two pathogenetic types based on clinical, metabolic, and endocrine characteristics: type I tumors (60-70\%), associated with estrogen excess, obesity, hormone-receptor positivity, and endometrial hyperplasia, with favorable 
outcomes, and type II tumors (30-40\%), more common in nonobese women, associated with an atrophic endometrium, with aggressive clinical behavior and poor outcome (2).

Adjuvant therapy recommendations have traditionally been based on the individual patient's risk of disease recurrence using clinicopathologic factors such as age, stage, histologic subtype, tumor grade, and lymphovascular space invasion (LVSI) $(3,4)$. In particular, the ESMO/ESGO/ESTRO (European Society for Medical Oncology-European Society for Radiotherapy and Oncology-European Society of Gynaecological Oncology) consensus in 2016 proposed five risk groups to guide adjuvant therapy use (low, intermediate, high-intermediate, high, advanced/metastatic) (4).

Overall, risk-adapted treatments achieve excellent prognosis for early-stage type I ECs, with 10-year overall survival exceeding $80 \%(5,6)$.

However, a small but substantial number of patients with favorable prognostic background unexpectedly experience recurrence of disease and poor survival (5-8), and it has been calculated that up to $10 \%$ of them will experience distant metastasis (7).

On the other hand, a not-negligible number of patients with unfavorable prognostic factors that are usually treated will never experience recurrence: in particular, seven high-intermediaterisk patients need to undergo vaginal brachytherapy (EBRT) to prevent one recurrence (7).

In 2013, the Cancer Genome Atlas (TCGA) defined four distinct EC subgroups (POLE mutated, microsatellite instability, low copy number, and high copy number) with possible prognostic value, and many others confirmed these data in external cohorts $(3-5,7,8)$. Molecular risk classes are not completely superimposable with clinicopathological categories, but the combination of both models has been shown to perform better in terms of prognosis than the single ones by themselves (7).

The most recent ESGO/ESTRO and the European Society of Pathology (ESP) ESP recommendations, published at the end of 2020, incorporated molecular and clinicopathological features in an integrated classification system in order to guide adjuvant treatment choices (9).

\section{A COMPREHENSIVE GENOMIC AND TRANSCRIPTOMIC ANALYSIS THROUGH NEXT-GENERATION SEQUENCING (NGS): A GENOMIC CLASSIFICATION}

In 2013, the Cancer Genome Atlas Research Network (TCGA) has reported a comprehensive genomic and transcriptomic analysis of 373 EC cases, mainly endometrioid (307) (8).

This characterization categorized EC tumors into four genomic classes with different molecular and prognostic profiles. Such molecular analyses were proven feasible (>96\%) and highly reproducible in external cohorts of patients $(7,10$, 11). The distribution of histologic subtypes into the four molecular classes is reported in Figure 1.

\section{POLEmut}

This molecular class is defined by pathogenic mutations in the exonuclease domain of DNA polymerase epsilon (10).

This gene encodes a catalytic subunit of DNA polymerase epsilon involved in nuclear DNA replication and repair. The most common alterations in POLE detected in EC samples are hotspot mutations at P286R, V411L, S297F, A456P, and S459F (10, 12-14).

Overall, this genomic class is associated with excellent prognosis. It accounts for less than $10 \%$ of all EC cases, and it is associated with low copy-number aberrations and a very high mutational burden $\left(232 \times 10^{-6}\right.$ mutations/Mb).

The associated morphological characteristics of this subgroup include high rate of tumor-infiltrating lymphocytes and/or peritumoral lymphocytes, morphologic heterogeneity/ ambiguity, bizarre/giant tumor cell nuclei, endometrioid histotype but also clear cell carcinomas, undifferentiated carcinomas, and carcinosarcomas $(13,15)$.

Approximately $65 \%$ of this molecular class is associated with intermediate and high-risk phenotype according to ESMO 2013 classification (16). In particular, it is frequently associated with grade 3 endometrioid cancers. Given the favorable prognosis of this subgroup, no adjuvant treatment could be suggested, reducing the possible overtreatment, particularly in the highintermediate- and high-risk group. The PORTEC-4a trial (ISRCTN11659025) will answer whether this strategy is safe and efficient in the high-intermediate-risk subgroup (17).

\section{Microsatellite Unstable (MSI Hypermutated)}

This molecular class is characterized by the presence of microsatellite instability.

MSI represents the phenotypic evidence that DNA mismatch repair (MMR) is not functioning normally. The MMR is a system for recognizing and repairing erroneous insertion, deletion, and misincorporation of bases that can arise during DNA replication and recombination, as well as repairing other forms of DNA damage.

The most common alteration in MMR detected in EC samples is MLH1 promoter methylation (8).

Overall, this genomic class is associated with intermediate prognosis.

It encounters for $25-30 \%$ of all EC cases and is characterized by low copy-number aberrations and high mutational burden $\left(18 \times 10^{-6}\right.$ mutations/Mb).

The associated morphological characteristics of this class include lower uterine segment location, mainly endometrioid histology, mucinous differentiation, tumor-infiltrating lymphocytes, peritumoral lymphocytes, and with lymphovascular space invasion, mainly substantial (18-20).

Approximately $30 \%$ of this molecular class is associated with the low-risk phenotype according to ESMO 2013 classification (16).

Around $10-14 \%$ of EC MMRd patients are estimated to have a Lynch syndrome. In particular, chances are higher in case of MSH2-/MSH6- or PMS2 - and lower in case of MLH1- (40 and $67 \%$ vs $2 \%)(21,22)$. 


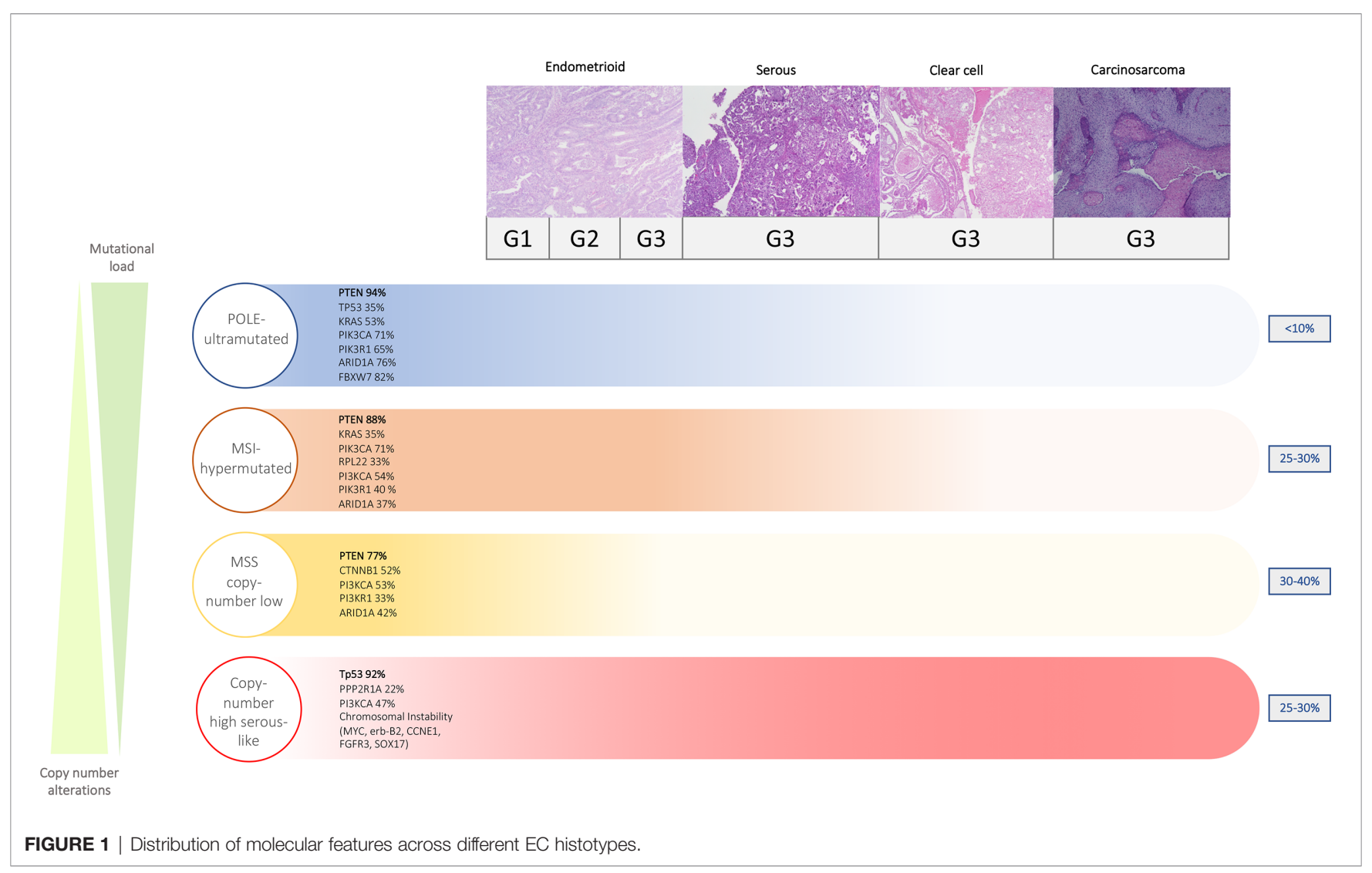

\section{Copy-Number High (Serous-Like)}

This genomic class is defined mainly by TP53 mutations (8).

P53 gene encodes for p53 protein (TP53) mainly involved in cell cycle arrest, DNA repair, senescence, apoptosis induction, but also cell metabolism regulation and cell response to oxidative stress (23).

Overall, this genomic class is associated with unfavorable prognosis.

It encounters for $25-30 \%$ of all EC cases and is characterized by a low mutation rate $\left(2.3 \times 10^{-6}\right.$ mutations/Mb) and high copy-number aberrations.

The associated morphological characteristics of this class include serous, endometrioid, and mixed serous and endometrioid histology, grade 3, poor inflammatory stroma (23).

Approximately $25 \%$ of this molecular class is associated with low- and intermediate-risk phenotypes according to ESMO 2013 classification (16). About $4 \%$ of EC are classified as multiple classifier at molecular profiling, and when POLE and p53abn coexist, the prognosis is driven by POLE. In the same way, when MMR-d and p53abn coexist, the prognosis is driven by MMRd (24).

\section{Copy-Number Low}

This genomic class comprises mainly microsatellite-stable cancers characterized by frequent CTNNB1 mutations (8).

Overall, this genomic class is associated with intermediate prognosis.
It encounters for $30-40 \%$ of all EC cases and is characterized by a low mutational burden $\left(2.9 \times 10^{-6}\right.$ mutations $\left./ \mathrm{Mb}\right)$ and low copy-number aberrations.

The associated morphological characteristics of this class include endometrioid histology, grade 1-2, very poor inflammatory stroma (25).

Approximately $50 \%$ of this molecular class is associated with the low-risk phenotype according to ESMO 2013 classification (16).

\section{FROM NGS TO \\ IMMUNOHISTOCHEMISTRY (IHC): THE MOLECULAR EC CLASSIFICATION}

Methodologies used for the TCGA study are costly, complex, and unsuitable for wider implementation in clinical practice. In 2015, a pragmatic molecular classifier based on surrogate immunohistochemistry assays was developed and validated in internal and external cohorts $(10,11,26,27)$. It was aimed at replicating and replacing the TCGA classification, which relied on whole-exome sequencing (WES). This approach was tested by multiple study groups, which makes evidences concerning its feasibility and reliability especially robust (28).

The "MSI hypermutated" group was identified as MMR deficient (MMRd) using MMR IHC testing (MLH1, MSH2, 
MSH6, and PMS2), and it showed high concordance with MSI assay by NGS.

The "high copy number" group was identified as p53abnormal (p53abn) determining p53 status by IHC testing; the subgroup obtained, however, was not completely equivalent to the TCGA one.

No surrogate was found for POLEmut detection; thus, NGS was maintained.

The "low copy number" group was determined by exclusion and called non-specific molecular profile (NSMP).

\section{INTEGRATED CLINICOPATHOLOGIC AND MOLECULAR CLASSIFICATION: THE ESGO/ESTRO/ESP 2020 RISK CLASSIFICATION AND ADJUVANT TREATMENT RECOMMENDATIONS}

The integration of molecular and clinicopathological factors in early-stage ECs in various PORTEC trials cohorts resulted in a stronger model with improved risk prognostication (7).

In particular, the AUC of the integrated molecular risk assessment showed a substantial improvement in predicting locoregional recurrence, distant recurrence, and overall survival compared to clinicopathological classification alone.

Its main implication is to guide clinicians' choices in terms of fertility-sparing treatments, surgery, adjuvant therapy, and surveillance in order to improve outcomes for women with EC.

In the light of available evidences, the ESGO/ESTRO/ESP decided to jointly update EC management evidence-based guidelines, implementing the use of molecular classification.

Risk group classification includes both cases that undergo molecular profiling and cases who did not. If molecular classification tools are not available, traditional pathologic features are used to classify EC patients. The main characteristics of the large trials included in the consensus, which guided treatment decision making, are summarized in Table $\mathbf{1}$.

Clinicopathological factors include the following:

- age

- International Federation of Gynecology and Obstetrics (FIGO) stage 2009

- depth of myometrial invasion

- tumor differentiation grade

- tumor type (endometrioid vs non-endometrioid)

- lymphovascular space involvement (LVSI)

Molecular features include the following:

- POLE mutation analysis by DNA sequencing

- p53 assessed by IHC

- MLH1, MSH2, MSH6, and PMS2 assessed by IHC

A consensus definition for LVSI in the literature is lacking. It reported good inter-observer agreement in discriminating "true LVSI" from "LVSI mimics" and in grading the extent of LVSI through a semiquantitative system (33). Nevertheless, some problematic cases exist. In addition, substantial LVSI in EC seems to have a stronger prognostic significance than focal LVSI (34-36).

Overall, the new ESTRO/ESGO/ESP guidelines published in 2020 integrate molecular into clinical classification and encouraged molecular classification in all EC especially highgrade tumors with only POLE mutation analysis possibly omitted in low-risk and intermediate-risk carcinoma with lowgrade histology. Based on this, p53abn tumors with myometrial invasion are considered and treated as high-risk patients with chemotherapy or the combination of chemotherapy and radiotherapy. Stage I-II POLEmut ECs without residual disease are considered low-risk patients for which no adjuvant treatment is recommended.

\section{Low-Risk Class}

This risk class includes patients with one of the following conditions:

- FIGO 2009 stage IA (<50\% myometrial invasion), endometrioid histology, grade 1 , LVSI negative

- POLEmut in FIGO 2009 stage I-II EC without residual disease

- MMRd/NSMP in FIGO 2009 stage IA G1, LVSI negative or focal

Routine lymphadenectomy for nodal staging purposes is generally not recommended for this group $(37,38)$. Sentinel lymph node biopsy can be considered for staging purposes, but it can be omitted in cases without myometrial invasion $(38,39)$. The incidence of recurrence after surgery alone is $<5 \%(40)$. No adjuvant treatment is recommended for this group.

\section{Intermediate-Risk Class}

This risk class includes patients with one of the following conditions:

- FIGO 2009 stage IB (<50\% myometrial invasion), endometrioid histology, grade 1-2, LVSI negative or focal

- FIGO 2009 Stage IA endometrioid, grade 3, LVSI negative or focal

- FIGO 2009 Stage IA non-endometrioid (serous, clear cell, undifferentiated carcinoma, carcinosarcoma, mixed) without myometrial invasion

- MMRd/NSMP in FIGO 2009 stage IB, endometrioid histology, grade $1-2$, LVSI negative or focal

- MMRd/NSMP in FIGO 2009 stage IA, endometrioid, G3, + high-grade, LVSI negative or focal

- p53abn in FIGO 2009 stage IA without myometrial invasion

Lymphadenectomy can be considered as a staging procedure to better tailor adjuvant treatment $(37,41)$.

The incidence of recurrence after surgery alone is between 5 and $10 \%(29,32,42,43)$.

EBRT is recommended to decrease vaginal recurrence since it has been shown to reduce the risk of local relapse $(29,32,42,43)$. Observation is an option, especially for patients aged $<60$ years (44). 
TABLE 1 | Relevant clinical trials for the ESGO/ESTRO/ESP consensus.

\begin{tabular}{|c|c|c|c|c|c|c|c|c|}
\hline $\begin{array}{l}\text { Clinical } \\
\text { trial }\end{array}$ & Reference & Years & $\begin{array}{l}\text { Numberof } \\
\text { patients } \\
\text { enrolled }\end{array}$ & Inclusion criteria & $\begin{array}{l}\text { Study } \\
\text { design }\end{array}$ & Treatments & Conclusions & Note \\
\hline $\begin{array}{l}\text { PORTEC- } \\
1\end{array}$ & $\begin{array}{l}\text { Creutzberg } \\
\text { et al. (29) } \\
\text { Lancet }\end{array}$ & $\begin{array}{c}1990- \\
1997\end{array}$ & 714 & $\begin{array}{l}\text { - Stage IC grade 1-2 } \\
\text { - Stage IB Grade 2-3 } \\
\text { - Endometrial } \\
\text { adenocarcinoma }\end{array}$ & $\begin{array}{l}\text { RCT } \\
1: 1\end{array}$ & $\begin{array}{l}\text { EBRT (46 Gy using } 2 \text { Gy } \\
\text { daily fractions) vs NAT }\end{array}$ & $\begin{array}{l}\text { EBRT significantly reduced } \\
\text { the risk of locoregional } \\
\text { recurrence, without survival } \\
\text { benefit. }\end{array}$ & $\begin{array}{l}\text { - Routine } \\
\text { lymphadenectomy not } \\
\text { performed }\end{array}$ \\
\hline $\begin{array}{l}\text { PORTEC- } \\
2\end{array}$ & $\begin{array}{l}\text { Nout et al. } \\
\text { (30) JCO }\end{array}$ & $\begin{array}{c}2002- \\
2006\end{array}$ & 427 & $\begin{array}{l}\text { - } \quad \text { Age }>60 \text {, stage } 1 \\
\text { grade } 1-2 \\
\text { - } \quad \text { Age }>60 \text {, stage } 1 \\
\text { grade } 3 \\
\text { - } \quad \text { Any age and stage } \\
2 \text { A grade } 1-2 \text { or grade } \\
3 \text { with }<50 \% \text { invasion }\end{array}$ & $\begin{array}{l}\text { RCT } \\
1: 1\end{array}$ & $\begin{array}{l}\text { Pelvic EBRT ( } 46 \text { Gy in } 23 \\
\text { fractions) vs VBT ( } 21 \text { Gy } \\
\text { HDR in } 3 \text { fractions, or } 30 \text { Gy } \\
\text { LDR) }\end{array}$ & $\begin{array}{l}\text { VBT is effective in preventing } \\
\text { vaginal recurrence. }\end{array}$ & $\begin{array}{l}\text { - Routine } \\
\text { lymphadenectomy not } \\
\text { performed }\end{array}$ \\
\hline $\begin{array}{l}\text { PORTEC- } \\
3\end{array}$ & $\begin{array}{l}\text { De Boer } \\
\text { et al. (31) } \\
\text { Lancet }\end{array}$ & $\begin{array}{l}2006- \\
2013\end{array}$ & 660 & $\begin{array}{l}\text { - Stage 1A } \\
\text { endometrioid grade 3, } \\
\text { LVSI+ } \\
\text { - } \quad \text { Stage IB } \\
\text { endometrioid grade } 3 \\
\text { - } \quad \text { Stage II } \\
\text { endometrioid } \\
\text { - } \quad \text { Stage IIIA, IIIB IIIC } \\
\text { endometrioid Serous } \\
\text { EC with invasion), IB, II, } \\
\text { or III. • Clear-cell EC } \\
\text { with stages IA (with } \\
\text { invasion), IB, II, or III. } \\
\text { stages IA (with }\end{array}$ & $\begin{array}{l}\text { RCT } \\
1: 1\end{array}$ & $\begin{array}{l}\text { EBRT ( } 48 \cdot 6 \text { Gy in } 1,8 \text { Gy } \\
\text { fractions given on } 5 \text { days } \\
\text { per week) vs radiotherapy } \\
\text { and chemotherapy } \\
\text { (consisting of two cycles of } \\
\text { cisplatin } 50 \mathrm{mg} / \mathrm{m} 2 \text { given } \\
\text { during } \\
\text { radiotherapy, followed by } \\
\text { four cycles of carboplatin } \\
\text { AUC5 and paclitaxel } 175 \\
\mathrm{mg} / \mathrm{m}^{2} \text { ) }\end{array}$ & $\begin{array}{l}\text { EBRT+CHT for high-risk } \\
\text { endometrial cancer did not } \\
\text { significantly improve overall } \\
\text { survival but improved 5-year } \\
\text { failure-free survival } \\
\text { compared with EBRT alone. }\end{array}$ & $\begin{array}{l}\text { - Routine } \\
\text { lymphadenectomy not } \\
\text { performed }\end{array}$ \\
\hline GOG-99 & $\begin{array}{l}\text { Keys et al. } \\
\text { (32) Gyn } \\
\text { Oncol }\end{array}$ & $\begin{array}{c}1987- \\
1995\end{array}$ & 392 & $\begin{array}{ll}\text { - } & \text { IB } \\
\text { - } & \mathrm{IC} \\
\text { - } & \mathrm{IA} \text { (occult) } \\
\text { - } & \mathrm{IB} \text { [occult] }\end{array}$ & $\begin{array}{l}\text { RCT } \\
1: 1\end{array}$ & $\begin{array}{l}\text { EBRT } 50.40 \text { Gy given more } \\
\text { than } 28 \text { fractions of } 180 \text { cGy } \\
\text { vs NAT }\end{array}$ & $\begin{array}{l}\text { EBRT decreases the risk of } \\
\text { recurrence, but should be } \\
\text { limited to high-intermediate- } \\
\text { risk patients. }\end{array}$ & $\begin{array}{l}\text { cycles of carboplatin } \\
\text { AUC5 and paclitaxel } \\
\left.175 \mathrm{mg} / \mathrm{m}^{2}\right) \text { Selective } \\
\text { bilateral pelvic, and } \\
\text { para-aortic } \\
\text { lymphadenectomy }\end{array}$ \\
\hline $\begin{array}{l}\text { ASTEC/ } \\
\text { EN5 }\end{array}$ & $\begin{array}{l}\text { ASTEC/ } \\
\text { EN.5 Study } \\
\text { Group, } \\
\text { Lancet } \\
2009\end{array}$ & $\begin{array}{l}1996- \\
2005\end{array}$ & 905 & $\begin{array}{l}\text { - } \text { FIGO stage IA G3 } \\
\text { - IB grade } 3 \\
\text { - } \quad \text { IC all grades } \\
\text { - } \quad \text { Papillary serous all } \\
\text { stages and grades } \\
\text { - } \quad \text { Clear-cell histology } \\
\text { all stages and grades }\end{array}$ & $\begin{array}{l}\text { RCT } \\
1: 1\end{array}$ & $\begin{array}{l}\text { EBRT (40- } 46 \text { Gy in } 20-25 \\
\text { daily fractions) vs NAT }\end{array}$ & $\begin{array}{l}\text { EBRT did not improve } \\
\text { overall survival compared to } \\
\text { observation. }\end{array}$ & $\begin{array}{l}\text { - Lymphadenectomy } \\
\text { as part of surgical } \\
\text { staging was not a } \\
\text { requirement }\end{array}$ \\
\hline
\end{tabular}

RCT, randomized control trials; EBRT, external beam radiotherapy; VBT, vaginal brachytherapy; CHT, chemotherapy; FIGO, International Federation of Gynecology and Obstetrics 1999; NAT, non-adjuvant treatment.

For p53abn FIGO 2009 stage IA without myometrial invasion cases, adjuvant treatment should be discussed on a case-by-case basis since specific data are missing.

\section{High-Intermediate-Risk Class}

This risk class includes patients with one of the following conditions:

- FIGO 2009 stage IA, regardless of grade or depth of invasion with LVSI unequivocally positive

- FIGO 2009 stage IB, grade 3, regardless of LVSI status

- FIGO 2009 Stage II

Lymphadenectomy for nodal staging purposes can be considered (45).

The incidence of recurrence after surgery alone is between 12 and $14 \%(29,32)$.

For those patients who underwent surgical nodal staging documenting negative nodes, VBRT is recommended to decrease vaginal recurrence, but no adjuvant therapy with close follow-up is an alternative acceptable option (4). In the case of substantial LVSI, EBRT can be considered in order to reduce the risk of pelvic and para-aortic nodal relapse (46). Similarly, cases displaying grade 3 tumors and/or substantial LVSI could benefit from adjuvant chemotherapy (31).

In patients for which lymph nodal status is unknown, VBRT is recommended for those patients who have LVSI negative, while EBRT is recommended for LVSI unequivocally positive to decrease pelvic recurrence $(31,46)$. Systemic therapy is considered of uncertain benefit (31).

\section{High-Risk Class}

This risk class includes patients with the following characteristics:

- FIGO 2009 stage I non-endometrioid (serous, clear cell, undifferentiated carcinoma, carcinosarcoma, mixed) with myometrial invasion, and with no residual disease 
- FIGO 2009 stage I p53abn endometrial carcinoma with myometrial invasion, with no residual disease.

There is no agreement on the role of lymphadenectomy in this risk class (4).

The 5-year incidence of recurrence (vaginal, pelvic, or distant) is around $41 \%(29,31,46)$.

For this class, EBRT with concurrent and adjuvant chemotherapy or alternatively sequential chemotherapy and radiotherapy is recommended $(29,31,46-48)$. However, chemotherapy additional benefit is unclear for patients with clear-cell carcinomas. Chemotherapy alone can be an alternative option (49).

\section{ADDITIONAL FEATURES}

Additional prognostic risk factors such as L1CAM and mutations in exon 3 of CTNNB1 later emerged and demonstrated to better mark differences in terms of prognosis among the four classes $(16,34,50-52)$. Overall, three different prognostic profiles were delineated (see Table 2).

These additional features and, as a consequence, these profiles were not included in the most recent guidelines but were adopted in PORTEC-4a study to assign adjuvant treatment in the experimental arm (17).

\section{CTNNB1}

CTNNB1 gene encodes $\beta$-catenin protein, involved in regulation and coordination of cell adhesion and cell signaling.

In particular, within the copy number low group, CTNNB1 exon 3 mutation status was found prognostic for distant recurrence in $\mathrm{EC}(7)$.

Although nuclear expression of $\beta$-catenin could be an IHC surrogate of CTNNB1 exon 3 mutations, NGS testing remains the gold standard (52-55).

CTNNB1 status helped distinguishing, within this class, a favorable group (CTNNB1-wild type) with a similar prognosis to POLEmut tumors, from an unfavorable group (CTNNB1mutant), with a similar prognosis to MMRd.

\section{L1CAM}

L1CAM is a 200 to $220 \mathrm{kDa}$ membrane glycoprotein of the immunoglobulin superfamily and is crucially involved in processes of neurogenesis (56).

The established $\geq 10 \%$ threshold for positivity was based on the cutoff that best correlated with prognosis (57). It has been shown that patients bearing L1CAM-positive cancers have poorer disease-free and overall survival (51).
L1CAM positivity was mainly, but not exclusively, found in intermediate- and high-risk cancers (13.2 vs 25.8\% in low and intermediate, respectively) (51). Moreover, it was associated with histopathological high grade and increasing depth of myometrium infiltration (58).

Given the association with an overwhelming increase in the likelihood of distal or local recurrence and poor overall survival, its presence indicates the need for adjuvant treatment $(51,59)$.

\section{CONCLUSIONS}

The traditional dualistic histopathologic classification that split EC into two groups, type I and type II cancer, is not more adherent to practical necessity of the clinicians. In recent years it has become increasingly clear that the traditional classification lacks reproducibility and yields heterogeneous molecular groups, hampering advances and implementation of precision medicine. This is particularly problematic for future clinical trials with targeted approaches that will demand inclusion of cancers with molecular similarities. The endometrial cancer classification proposed by TCGA would serve this purpose well, as it is based upon the combination of somatic mutational burden and somatic copy number alterations. Moreover, several publications on large and clinically well annotated (trial) cohorts have shown that surrogate IHC markers can be utilized for a TCGA-inspired molecular classification in routine surgical pathology, without the need for extensive sequencing. These surrogate markers have been extensively studied and show good performance. The prognostic value has been well established, with POLEmut EC having an excellent outcome and p53abn EC having the poorest clinical outcome, independent of risk group, type of adjuvant treatment, tumor type, or grade. This implies that de-escalation of adjuvant treatment for POLEmut EC patients should be explored, as is currently being done in the clinical PORTEC4a trial. Furthermore, recent data strongly suggest that the benefit for the addition of chemotherapy in the adjuvant treatment is limited to p53mut EC, which includes most serous cancers but also a significant portion of other histologic subtypes such as carcinosarcomas, thus suggesting an escalation of adjuvant treatment with chemotherapy combined with radiation when p53 mutation is detected. The implementation of molecular classification into clinical classification has the potential to serve in improving patient management by reducing over- and undertreatment (60). The use of this novel classification in routine clinical practice and future trial designs should be encouraged. Currently, one trial (PORTEC-4a) is ongoing to determine whether adjuvant treatment can be based on a molecular-integrated risk profile rather than standard

TABLE 2 | Three different prognostic profiles in FIGO 2009 Stage I EC, delineated including additional molecular factors.

\begin{tabular}{lllll}
\hline & FAVORABLE & & INTERMEDIATE & UNFAVORABLE \\
\hline Characteristics & POLE mut OR & PSMP CTNNB1 WT & NSMP CTNNB1 mut & P53abn \\
& & N & MMRd & LVSI substantial \\
& & & & $>10 \%$ L1CAM
\end{tabular}


clinicopathological risk factors in high-intermediate-risk EC patients. The preliminary report of the first 50 patients enrolled showed that molecular assessment is feasible, but patients' acceptance rate was not completely satisfactory (around $35 \%)(17)$.

Nevertheless, possible technical limits such as the need of assay harmonization as well as the lengthening of reporting times should be addressed.

\section{REFERENCES}

1. WHO. GLOBOCAN 2012: Estimated Cancer Incidence, Mortality and Prevalence Worldwide in 2012 (2012). Available at: http://globocan.iarc.fr/ Pages/fact_sheets_population.aspx (Accessed 3 April 2015, date last accessed).

2. Bokhman JV. Two Pathogenetic Types of Endometrial Carcinoma. Gynecol Oncol (1983) 15:10 - 17. doi: 10.1016/0090-8258(83)90111-7

3. Abu-Rustum NR, Yashar CM, Bradley K, Campos SM, Chino J, Chon HS, et al. National Comprehensive Cancer Network Clinical Practice Guidelines in Oncology (NCCN Guidelines ${ }^{\circledR}$ ) Uterine Neoplasms; Version 2.2020 (2020).

4. Colombo N, Creutzberg C, Amant F, Bosse T, González-Martín A, Ledermann J, et al. ESMO-ESGO-ESTRO Consensus Conference on Endometrial Cancer:diagnosis, treatment and follow-up. Ann Oncol (2016) 27(1):16-41. doi: 10.1093/annonc/mdv484. Erratum in: Ann Oncol. $2017 \mathrm{Jul}$ 1;28(suppl_4):iv167-iv168.

5. Fung-Kee-Fung M, Dodge J, Elit L, Lukka H, Chambers A, Oliver T. FollowUp After Primary Therapy for Endometrial Cancer: A Systematic Review. Cancer Care Ontario Program in Evidencebased Care Gynecology Cancer Disease Site Group. Gynecol Oncol (2006) 101(3):520-9. doi: 10.1016/ j.ygyno.2006.02.011

6. Lajer H, Jensen MB, Kilsmark J, Albæk J, Svane D, Mirza MR, et al. The Value of Gynecologic Cancer Follow-Up: Evidence-Based Ignorance? Int J Gynecol Cancer (2010) 20(8):1307-20. doi: 10.1111/IGC.0b013e3181 f3bee 0

7. Stelloo E, Nout RA, Osse EM, Jürgenliemk-Schulz IJ, Jobsen JJ, Lutgens LC, et al. Improved Risk Assessment by Integrating Molecular and Clinicopathological Factors in Early-Stage Endometrial Cancer-Combined Analysis of the PORTEC Cohorts. Clin Cancer Res (2016) 22(16):4215-24. doi: 10.1158/1078-0432.CCR-15-2878

8. Kandoth C, Schultz N, Cherniack AD, Akbani R, Liu Y, Shen H, et al. Integrated Genomic Characterization of Endometrial Carcinoma. Nature (2013) 497:67-73. doi: 10.1038/nature12113

9. Concin N, Matias-Guiu X, Vergote I, Cibula D, Mirza MR, Marnitz S, et al. ESGO/ESTRO/ESP Guidelines for the Management of Patients With Endometrial Carcinoma. Int J Gynecol Cancer (2021) 31(1):12-39. doi: 10.1136/ijgc-2020-002230

10. Talhouk A, McConechy MK, Leung S, Yang W, Lum A, Senz J, et al. Confirmation of ProMisE: Asimple, Genomics-Based Clinical Classifier for Endometrial Cancer. Cancer (2017) 123(5):802- 813. doi: 10.1002/cncr.30496

11. Stelloo E, Bosse T, Nout RA, MacKay HJ, Church DN, Nijman HW, et al. Refining Prognosis and Identifying Targetable Pathways for High-Risk Endometrial Cancer; a TransPORTEC Initiative. Mod Pathol (2015) 28 (6):836-44. doi: 10.1038/modpathol.2015.43

12. Hussein YR, Weigelt B, Levine DA, Schoolmeester JK, Dao LN, Balzer BL, et al. Clinicopathological Analysis of Endometrial Carcinomas Harboring Somatic POLE Exonuclease Domain Mutations. Mod Pathol (2015) 28 (4):505-14. doi: 10.1038/modpathol.2014.143

13. León-Castillo A, Britton H, McConechy MK, McAlpine JN, Nout R, Kommoss S, et al. Interpretation of Somatic POLE Mutations in Endometrial Carcinoma. J Pathol (2020) 250(3):323-35. doi: 10.1002/ path. 5372

14. DeLair DF, Burke KA, Selenica P, Lim RS, Scott SN, Middha S, et al. The Genetic Landscape of Endometrial Clear Cell Carcinomas. J Pathol (2017) 243 (2):230-41. doi: 10.1002/path.4947

15. Kobel M, Hoang LN, Tessier-Cloutier B, Meng B, Soslow RA, Stewart CJR, et al. Undifferentiated Endometrial Carcinomas Show Frequent Loss of Core

\section{AUTHOR CONTRIBUTIONS}

CN: Conceptualization; Metholodology; Data curation; Roles/ Writing - original draft; FC: Data curation; AP: Data curation; SD: Data curation; GD: Supervision; Writing - review \& editing. GS: Supervision; Writing - review \& editing. DL: Funding acquisition; Supervision; Writing - review \& editing. All authors contributed to the article and approved the submitted version.

Switch/Sucrose Nonfermentable Complex Proteins. Am J Surg Pathol (2017) 42(1):76-83. doi: 10.1097/PAS.0000000000000941

16. Talhouk A, McConechy MK, Leung S, Li-Chang HH, Kwon JS, Melnyk N, et al. A Clinically Applicable Molecular-Based Classification for Endometrial Cancers. Br J Cancer (2015) 113:299-310. doi: 10.1038/bjc. 2015.190

17. Wortman BG, Bosse T, Nout RA, Lutgens LCHW, van der Steen-Banasik EM, Westerveld $\mathrm{H}$, et al. Molecular-Integrated Risk Profile to Determine Adjuvant Radiotherapy in Endometrial Cancer: Evaluation of the Pilot Phase of the PORTEC-4a Trial. Gynecol Oncol (2018) 151(1):69-75. doi: 10.1016/ j.ygyno.2018.07.020

18. Broaddus RR, Lynch HT, Chen LM, Daniels MS, Conrad P, Munsell MF, et al. Pathologic Features of Endometrial Carcinoma Associated With HNPCC: A Comparison With Sporadic Endometrial Carcinoma. Cancer (2006) 106 (1):87-94. doi: $10.1002 / \mathrm{cncr} .21560$

19. Jinru S, Black D, Hummer AJ, Boyd J, Robert A. Soslow Routinely Assessed Morphological Features Correlate With Microsatellite Instability Status in Endometrial Cancer. Hum Pathol (2008) 39(1):116-25. doi: 10.1016/ j.humpath.2007.05.022

20. Rabban JT, Calkins SM, Karnezis AN, Grenert JP, Blanco A, Crawford B, et al. Association of Tumor Morphology With Mismatch-Repair Protein Status in Older Endometrial Cancer Patients: Implications for Universal Versus Selective Screening Strategies for Lynch Syndrome. Am J Surg Pathol (2014) 38(6):793-800. doi: 10.1097/PAS.0000000000000177

21. Kim SR, Tone A, Kim RH, Cesari M, Clarke BA, Eiriksson L, et al. Maximizing Cancer Prevention Through Genetic Navigation for Lynch Syndrome Detection in Women With Newly Diagnosed Endometrial and Nonserous/ Nonmucinous Epithelial Ovarian Cancer. Cancer (2021) 127(17):3082-91. doi: 10.1002/cncr.33625

22. Post CCB, Stelloo E, Smit VTHBM, Ruano D, Tops CM, Vermij L, et al. Prevalence and Prognosis of Lynch Syndrome and Sporadic Mismatch Repair Deficiency in Endometrial Cancer. J Natl Cancer Inst (2021) 6:djab029. doi: 10.1093/jnci/djab029

23. Perri F, Pisconti S, Della Vittoria Scarpati G. P53 Mutations and Cancer: A Tight Linkage. Ann Transl Med (2016) 4(24):522. doi: 10.21037/ atm.2016.12.40

24. León-Castillo A, Gilvazquez E, Nout R, Smit VT, McAlpine JN, McConechy $\mathrm{M}$, et al. Clinicopathological and Molecular Characterisation of 'MultipleClassifier' Endometrial Carcinomas. J Pathol (2020) 250(3):312-22. doi: 10.1002/path. 5373

25. Kurnit KC, Kim GN, Fellman BM, Urbauer DL, Mills GB, Zhang W, et al. CTNNB1 (Beta-Catenin) Mutation Identifies Low Grade, Early Stage Endometrial Cancer Patients at Increased Risk of Recurrence. Mod Pathol (2017) 30(7):1032-41. doi: 10.1038/modpathol.2017.15

26. Bakhsh S, Kinloch M, Hoang LN, Soslow RA, Köbel M, Lee CH, et al. Histopathological Features of Endometrial Carcinomas Associated With POLE Mutations: Implications for Decisions About Adjuvant Therapy. Histopathology (2016) 68(6):916-24. doi: 10.1111/his.12878

27. Kommoss S, McConechy MK, Kommoss F, Leung S, Bunz A, Magrill J, et al. Final Validation of the ProMisE Molecular Classifier for Endometrial Carcinoma in a Large Population-Based Case Series. Ann Oncol (2018) 29 (5):1180-8. doi: 10.1093/annonc/mdy058

28. McConechy MK, Talhouk A, Li-Chang HH, Leung S, Huntsman DG, Gilks $\mathrm{CB}$, et al. Detection of DNA Mismatch Repair (MMR) Deficiencies by Immunohistochemistry can Effectively Diagnose the Microsatellite Instability (MSI) Phenotype in Endometrial Carcinomas. Gynecol Oncol (2015) 137(2):306-10. doi: 10.1016/j.ygyno.2015.01.541 
29. Creutzberg CL, van Putten WL, Koper PC, Lybeert ML, Jobsen JJ, Wárlám-Rodenhuis CC, et al. Surgery and Postoperative Radiotherapy Versus Surgery Alone for Patients With Stage-1 Endometrial Carcinoma: Multicentre Randomised Trial. PORTEC Study Group. Post Operative Radiation Therapy in Endometrial Carcinoma. Lancet (2000) 355:1404-11. doi: 10.1016/S0140-6736(00)02139-5

30. Nout RA, Smit VT, Putter H, Jürgenliemk-Schulz IM, Jobsen JJ, Lutgens LC, et al. Vaginal Brachytherapy Versus Pelvic External Beam Radiotherapy for Patients With Endometrial Cancer of High-Intermediate Risk (PORTEC-2): An Open-Label, Non-Inferiority, Randomised Trial. Lancet (2010) 375 (9717):816-23. doi: 10.1016/S0140-6736(09)62163-2

31. de Boer SM, Powell ME, Mileshkin L, Katsaros D, Bessette P, Haie-Meder C, et al. Adjuvant Chemoradiotherapy Versus Radiotherapy Alone for Women With High-Risk Endometrial Cancer (PORTEC-3): Final Results of an International, Open-Label, Multicentre, Randomised, Phase 3 Trial. Lancet Oncol (2018) 19:295-309.

32. Keys HM, Roberts JA, Brunetto VL, Zaino RJ, Spirtos NM, Bloss JD, et al. A Phase III Trial of Surgery With or Without Adjunctive External Pelvic Radiation Therapy in Intermediate Risk Endometrial Adenocarcinoma: A Gynecologic Oncology Group Study. Gynecol Oncol (2004) 92:744-51. doi: 10.1016/j.ygyno.2003.11.048

33. Peters EEM, Bartosch C, McCluggage WG, Genestie C, Lax SF, Nout R, et al. Reproducibility of Lymphovascular Space Invasion (LVSI) Assessment in Endometrial Cancer. Histopathology (2019) 75(1):128-36. doi: 10.1111/ his. 13871

34. Bosse T, Peters EEM, Creutzberg CL, Jürgenliemk-Schulz IM, Jobsen JJ, Mens JW, et al. Substantial Lymph-Vascular Space Invasion (LVSI) Is a Significant Risk Factor for Recurrence in Endometrial Cancer - A Pooled Analysis of PORTEC 1 and 2 Trials. Eur J Cancer (2015) 51(13):1742-50. doi: 10.1016/j.ejca.2015.05.015

35. Winer I, Ahmed QF, Mert I, et al. Significance of Lymphovascular Space Invasion in Uterine Serous Carcinoma: What Matters More; Extent or Presence? Int J Gynecol Pathol (2015) 34:47-56. doi: 10.1097/PGP. 0000000000000113

36. Tortorella L, Restaino S, Zannoni GF, Vizzielli G, Chiantera V, Cappuccio S, et al. Substantial Lymph-Vascular Space Invasion (LVSI) as Predictor of Distant Relapse and Poor Prognosis in Low-Risk Early-Stage Endometrial Cancer. J Gynecol Oncol (2021) 32(2):e11. doi: 10.3802/jgo.2021.32.e11

37. Benedetti Panici P, Basile S, Maneschi F, Alberto Lissoni A, Signorelli M, Scambia G, et al. Systematic Pelvic Lymphadenectomy vs. No Lymphadenectomy in Early-Stage Endometrial Carcinoma: Randomized Clinical Trial. J Natl Cancer Inst (2008) 100:1707-16.

38. Frumovitz M, Plante M, Lee PS, Sandadi S, Lilja JF, Escobar PF, et al. NearInfrared Fluorescence for Detection of Sentinel Lymph Nodes in Women With Cervical and Uterine Cancers (FILM): A Randomised, Phase 3, Multicentre, Non-Inferiority Trial. Lancet Oncol (2018) 19:1394-403. doi: 10.1016/S1470-2045(18)30448-0

39. Ignatov A, Lebius C, Ignatov T, Ivros S, Knueppel R, Papathemelis T, et al. Lymph Node Micrometastases and Outcome of Endometrial Cancer. Gynecol Oncol (2019) 154:475-9. doi: 10.1016/j.ygyno.2019.07.018

40. Sorbe B, Nordström B, Mäenpää J, Kuhelj J, Kuhelj D, Okkan S, et al. Intravaginal Brachytherapy in FIGO Stage I Low-Risk Endometrial Cancer: A Controlled Randomized Study. Int J Gynecol Cancer (2009) 19:873-8. doi: 10.1111/IGC.0b013e3181a6c9df

41. ASTEC study group, Kitchener H, Swart AM, Qian Q, Amos C, Parmar MK. Efficacy of Systematic Pelvic Lymphadenectomy in Endometrial Cancer (MRC ASTEC Trial): A Randomised Study. Lancet (2009) 373:125-36. doi: 10.1016/S0140-6736(08)61766-3

42. ASTEC/EN.5 Study Group, Blake P, Swart AM, Orton J, Kitchener H, Whelan T, et al. Adjuvant External Beam Radiotherapy in the Treatment of Endometrial Cancer (MRC ASTEC and NCIC CTG EN.5 Randomised Trials): Pooled Trial Results, Systematic Review, and Meta-Analysis. Lancet (2009) 373:137-46. doi: 10.1016/S0140-6736(08)61767-5

43. Kong A, Johnson N, Kitchener HC, Lawrie TA. Adjuvant Radiotherapy for Stage I Endometrial Cancer: An Updated Cochrane Systematic Review and Meta-Analysis. J Natl Cancer Inst (2012) 104:1625-34. doi: 10.1093/jnci/ djs374
44. Ortoft G, Hansen ES, Bertelsen K. Omitting Adjuvant Radiotherapy in Endometrial Cancer Increases the Rate of Locoregional Recurrences But has No Effect on Long-Term Survival: The Danish Endometrial Cancer Study. Int J Gynecol Cancer (2013) 23:1429-3. doi: 10.1097/IGC.0b013e3182a5e77d

45. Kim HS, Suh DH, Kim MK, Chung HH, Park NH, Song YS. Systematic Lymphadenectomy for Survival in Patients With Endometrial Cancer: A Meta-Analysis. Jpn J Clin Oncol (2012) 42:405-12. doi: 10.1093/jjco/hys019

46. Randall ME, Filiaci V, McMeekin DS, von Gruenigen V, Huang H, Yashar CM, et al. Phase III Trial: Adjuvant Pelvic Radiation Therapy Versus Vaginal Brachytherapy Plus Paclitaxel/Carboplatin in HighIntermediate and High-Risk Early-Stage Endometrial Cancer. JCO (2019) 37:1810-8. doi: 10.1200/JCO.18.01575

47. Hogberg T, Signorelli M, de Oliveira CF, Fossati R, Lissoni AA, Sorbe B, et al. Sequential Adjuvant Chemotherapy and Radiotherapy in Endometrial Cancer-Results From Two Randomised Studies. Eur J Cancer (2010) 46:2422-31. doi: 10.1016/j.ejca.2010.06.002

48. McMeekin DS, Filiaci VL, Aghajanian C, Rutherford TJ, Van Le L, Randall ME. A Randomized Phase III Trial of Pelvic Radiation Therapy (PXRT) Versus Vaginal Cuff Brachytherapy Followed by Paclitaxel/ Carboplatin Chemotherapy (VCB/C) in Patients With High Risk (HR), Early Stage Endometrial Cancer (EC): A Gynecologic Oncology Group Trial. Gynecol Oncol (2014) 134:438 (abstract LBA 431). doi: 10.1016/ j.ygyno.2014.07.078

49. Matei D, Filiaci V, Randall ME, Mutch D, Steinhoff MM, DiSilvestro PA, et al. Adjuvant Chemotherapy Plus Radiation for Locally Advanced Endometrial Cancer. N Engl J Med Overseas Ed (2019) 380:2317-26. doi: 10.1056/ NEJMoa1813181

50. Bosse T, Nout RA, Stelloo E, Dreef E, Nijman HW, Jürgenliemk-Schulz IM, et al. VTHBM Smit L1 Cell Adhesion Molecule Is a Strong Predictor for Distant Recurrence and Overall Survival in Early Stage Endometrial Cancer: Pooled PORTEC Trial Result. Eur J Cancer (2014) 50(15):2602-10. doi: 10.1016/j.ejca.2014.07.014

51. Zeimet AG, Reimer D, Huszar M, Winterhoff B, Puistola U, Azim SA, et al. L1CAM in Early-Stage Type I Endometrial Cancer: Results of a Large Multicenter Evaluation. J Natl Cancer Inst (2013) 105(15):1142-50. doi: 10.1093/jnci/djt144

52. van der Putten LJ, Visser NC, van de Vijver K, Santacana M, Bronsert P, Bulten J, et al. L1CAM Expression in Endometrial Carcinomas: An ENITEC Collaboration Study. Br J Cancer (2016) 115(6):716-24. doi: 10.1038/ bjc. 2016.235

53. Kim G, Kurnit KC, Djordjevic B, Singh C, Munsell MF, Wang WL, et al. Nuclear $\beta$-Catenin Localization and Mutation of the CTNNB1 Gene: A Context-Dependent Association. Mod Pathol (2018) 31(10):1553-9. doi: 10.1038/s41379-018-0080-0

54. Travaglino A, Raffone A, Saccone G, De Luca C, Mollo A, Mascolo M, et al. Immunohistochemical Nuclear Expression of $\beta$-Catenin as a Surrogate of CTNNB1 Exon 3 Mutation in Endometrial Cancer. Am J Clin Pathol (2019) 151(5):529-38. doi: 10.1093/ajcp/aqy178

55. Dong F, Costigan DC, Howitt BE. Targeted Next-Generation Sequencing in the Detection of Mismatch Repair Deficiency in Endometrial Cancers. Mod Pathol (2019) 32(2):252-7. doi: 10.1038/s41379-018-0125-4

56. Schaefer MK, Altevogt P. L1CAM Malfunction in the Nervous System and Human Carcinomas. Cell Mol Life Sci (2010) 67(14):2425-37. doi: 10.1007/ s00018-010-0339-1

57. Klat J, Mladenka A, Dvorackova J, Bajsova S, Simetka O. L1CAM as a Negative Prognostic Factor in Endometrioid Endometrial Adenocarcinoma FIGO Stage IA-IB. Anticancer Res (2019) 39(1):421-4. doi: 10.21873/ anticanres. 13128

58. de Freitas D, Aguiar FN, Anton C, Bacchi CE, Carvalho JP, Carvalho FM. L1 Cell Adhesion Molecule (L1CAM) Expression in Endometrioid Endometrial Carcinomas: A Possible Pre-Operative Surrogate of Lymph Vascular Space Invasion. PLoS One (2018) 13(12):e0209294. doi: 10.1371/journal.pone. 0209294

59. Corrado G, Laquintana V, Loria R, Carosi M, de Salvo L, Sperduti I, et al. Endometrial Cancer Prognosis Correlates With the Expression of L1CAM and miR34a Biomarkers. J Exp Clin Cancer Res (2018) 37(1):139. doi: 10.1186/ s13046-018-0816-1 
60. Cherniack AD, Shen H, Walter V, Stewart C, Murray BA, Bowlby R, et al. Integrated Molecular Characterization of Uterine Carcinosarcoma. Cancer Cell (2017) 31(3):411-23.

Conflict of Interest: The authors declare that the research was conducted in the absence of any commercial or financial relationships that could be construed as a potential conflict of interest.

Publisher's Note: All claims expressed in this article are solely those of the authors and do not necessarily represent those of their affiliated organizations, or those of the publisher, the editors and the reviewers. Any product that may be evaluated in this article, or claim that may be made by its manufacturer, is not guaranteed or endorsed by the publisher.

Copyright (๑) 2021 Nero, Ciccarone, Pietragalla, Duranti, Daniele, Scambia and Lorusso. This is an open-access article distributed under the terms of the Creative Commons Attribution License (CC BY). The use, distribution or reproduction in other forums is permitted, provided the original author(s) and the copyright owner(s) are credited and that the original publication in this journal is cited, in accordance with accepted academic practice. No use, distribution or reproduction is permitted which does not comply with these terms. 